\title{
Four new Australian species of Craspedia sens. strict. (Asteraceae: Gnaphalieae)
}

\author{
J. Everett and A.N.L. Doust
}

\begin{abstract}
Everett, I. and Doust, A.N.L. (National Herbarium of New South Wales, Royal Botanic Gardens, Sydney, NSW, Australia 2000) 1992. Four new species of Craspedia sens. strict. (Asteraceae: Gnaphalieae). Telopea 5(1): 35-38. The new species Craspedia paludicola, C. variabilis, C. canens and C. haplorrhiza are described. Notes on the flowering periods, habitat and general distribution are included.
\end{abstract}

\section{Introduction}

Prior to the publication of an account of Craspedia Forst. f. (Asteraceae: Gnaphalieae) in volume 3 of the Flora of New South Wales it is necessary to describe the following four species.

This paper deals with species of Craspedia sens. strict., that is those plants with pedunculate capitula within the compound head, but excludes those of alpine and subalpine regions. Further papers in this volume deal with alpine and subalpine Craspedia species, and those species with sessile capitula that have been removed to the reinstated genus Pycnosorus. All specimens cited have been seen unless otherwise indicated.

\section{C. paludicola Everett $\mathcal{E}$ Doust, sp. nov.}

Species foliis atroviridibus longe oblongis, basibus foliorum late vaginantibus, a speciebus nobis notis distincta.

TYPE: VICTORIA: Region L: Top End Reference Area Barmah State Park, Murray Valley Study Area Sector: F, sub-block: 41B, A.C. Beauglehole 81321, 28 Sep 1985 (holo MEL 681491; iso NSW, CANB, HO n.v.).

Robust herb with large dark olive-green flaccid leaves usually tinged deep red at the base, with one to three flowering scapes to $75 \mathrm{~cm}$ high; roots thick, tomentose. Leaves basal and cauline, narrow-obovate, obtuse, attenuate and broadly stem-clasping at the base, $15-30 \mathrm{~cm}$ long, 8-20 mm wide, with one to several prominent longitudinal veins, glabrous or with few scattered long, fine, tangled hairs or multi-septate hairs, or these denser on the margins or mid-vein; old leaf bases retained. Inflorescence a single globular, terminal compound head. Scape purplish with scattered long fine hairs. Compound head $1.7-3.0 \mathrm{~cm}$ in diameter with up to 300 partial heads. Partial heads with 7-12 florets; main bract of the partial involucre broadly triangular to ovate, with a small, diffuse, ovate herbaceous stereome with silky hairs at the base and glandular hairs overall, the margins membranous. Corolla bright yellow; achenes 1-1.8 mm long, $0.5-1.0 \mathrm{~mm}$ diam., with dense appressed silky hairs; pappus of 13-17 plumose bristles 3-4 $\mathrm{mm}$ long.

DERIVATION: From the Latin paludis, a marsh, and -cola, a dweller; referring to the swampy habitat. 
FLOWERING PERIOD: Spring to summer.

HABITAT: Restricted to swampy areas and drainlines, and often grows with its leaves partly submerged.

Distribution: Tasmanian midlands, Victoria and southern New South Wales, particularly associated with the Murray River system.

Can be distinguished by its long, oblong, very dark green leaves, with very broad leaf bases.

Selected sPecimens: New South Wales: South Western Plains: Narrandera-Ganmain, Moore 1373, 6 Sep 1950 (CANB). VICTORIA: $4 \mathrm{~km} \mathrm{~W}$ of Poolaijelo, Short 3245, 27 Sep 1988 (MEL, BRI n.v., CANB n.v., NSW); Goulburn River State Forest, Beauglehole 80289, 10 Sep 1985 (NSW, MEL); 2 km NW of Conara, Buchanan 7290, 12 Oct 1985 (NSW, MEL). TASMANIA: Roadside c. 2 km north west of Conara, A.M. Buchanan 7290, 12 Oct 1985 (HO, NSW n.v., MEL n.v.).

\section{C. variabilis Everett and Doust, sp. nov.}

Species foliis anguste spathulatis pilis plurisegmentatis grossis, a speciebus nobis notis distincta.

TYPE: SOUTH Australia: South Eastern Region: c. $15 \mathrm{~km}$ south-east of Mt Burr Township, I.B. Wilson 511, 7 Sep 1966 (holo AD; iso CANB).

Erect herb with one to several flowering scapes to $50 \mathrm{~cm}$ high, branched simply at the base, with thick, spreading woolly roots and broad, reddish, overlapping leaf-bases retained at the base. Leaves in a basal rosette and cauline, narrow-spathulate, 5-13 $\mathrm{cm}$ long, 5-13 mm wide, broad-acute, gland-tipped, pale to olive-green, with glandular hairs and multi-septate hairs and with very sparse long fine simple hairs. Inflorescence a globose terminal compound head. Scape straw-coloured to reddish, with multi-septate hairs and a few long fine hairs. Compound head 10-25 mm diam., with c. 40-100 partial heads. Partial heads prominently pedunculate, with 7-12 florets; main bract of the partial involucre ovate-cordate to broadly triangular, decurrent on the peduncle, with an ovate, glandular, herbaceous stereome, finely and sparsely woolly at the base, and with a colourless to brown, membranous lamina. Corolla golden-yellow; lobes broad-acute, conspicuously papillate on the inner surface; achenes 1.5-2.5 mm long, with fine, appressed, short, silky hairs; pappus of 13-21 colourless, plumose bristles $3-5 \mathrm{~mm}$ long.

DERIVATION: Refers to the number of different forms across its wide distribution.

FLOWERING PERIOD: Early spring to early summer.

HABITAT: A wide variety of habitats but never alpine.

DisTRIBUTION: In temperate regions of all mainland States except the Northern Territory.

This is a complex species with several forms, some of which may be separable on further work. It can be distinguished from other species in its geographical range by the narrow-spathulate leaves, with long, coarse, multi-septate hairs. This species is referred to as sp. C (in part), sp. $M$ and sp. $N$ in Jacobs \& Pickard (1981).

Selected specimens: Western Australia: South West Botanical Province: $22 \mathrm{~km}$ from York towards Perth along Great Southern Highway, Short 1660, 5 Sep 1982 (MEL, NSW, PERTH, CANB). South Australia: Eyre Penisula: Marble Range, slopes of North Block, Weber 6018, 30 Sep 1979 (AD, BRI). New South WaLEs: Central Western Slopes: Dubbo, Boorman, Aug 1903 (NSW 217241). South Western Plains: Vermont Hill Reserve, Cunningham \& Milthorpe, 29 Sep 1978 (NSW 217237). 


\section{C. canens Everett \& Doust, sp. nov. \\ C. variabili similis sed foliis incanis pilis tenuis differt.}

TYPE: NEW SOUTH WALES: Central Tablelands: Wingecarribee [Wingicarribee] Swamp $34^{\circ} 30^{\prime} \mathrm{S} 150^{\circ} 30^{\prime} \mathrm{E}$, L.A. Craven 1981, 26 Oct 1971 (holo NSW 221409 (ex CANB); iso CANB, L n.v.).

Herb with 1 , or occasionally up to 5, flowering scapes $15-65 \mathrm{~cm}$ high; roots thick, spreading, tomentose. Leaves mainly basal, narrow-ovate, attenuate to long-attenuate, acute to broad-acuminate, 6-25 cm long, 5-15 mm diam.; upper surface with long fine white hairs, evenly covering the surface or confined to the main veins and leaf margins, minute glandular hairs sometimes present; lower surface covered with long fine white hairs, occasionally with minute glandular hairs. Inflorescence a single globose to hemispherical terminal compound head. Scape green to purplish, minutely glandular and often woolly with long fine hairs. Compound head $1.3-2.5 \mathrm{~cm}$ diam., with c. 100 partial heads. Partial heads with 5-9 florets; main bract of the partial involucre ovate with a narrow-ovate to deltoid herbaceous stereome with a membranous lamina tinged brown. Corolla yellow; achenes 1-1.5 $\mathrm{mm}$ long, with fine appressed short silky hairs; pappus of 14-17 colourless plumose bristles $2.5-4 \mathrm{~mm}$ long.

Derivation: From the Latin canus, referring to the greyish whiteness of the leaves, caused by hairs overlying the green of the lamina.

FLOWERING PERIOD: Early spring to summer.

НАВІтАт: In wet or dry situations in open woodland or grassland.

Distribution: On Australia's east coast and tablelands, from southern Queensland southwards.

This is a complex species with several forms, some of which may be separable on further work. It can be distinguished from other species in its geographical range by the hoary leaf surfaces. This species is in part referred to as sp. C in Jacobs \& Pickard (1981).

Selected specimens: QueEnsland: Darling Downs: Racecourse Creek near Mt Norman, L. Pedley 1568, 31 Oct 1963 (BRI, CANB). New South Wales: South Coast: 4 miles [6 km] W of Green Cape, Constable, 10 Oct 1954 (NSW 30388). Northern Tablelands: Barrington Tops, Boorman, Dec 1915 (NSW 241489). Central Tablelands: Wingecarribee Swamp, near Burrawang, Pullen 8521 (NSW, BRI, PERTH, CANB). VICTORIA: 2 miles [3 km] ESE from Morwell, Jernakov, 12 Oct 1963 (MEL 1534649).

\section{C. haplorrhiza Everett $\&$ Doust, sp. nov.}

C. variabili similis sed radice palari differt.

TrPe: New South Wales: South Far Western Plains: southern crossroad, north of Ranger's Station, Kinchega National Park, A. Denham 039, 12 Sep 1989 (holo NSW; iso $\mathrm{AD})$.

Erect herb with one to many flowering scapes $7-15 \mathrm{~cm}$ high, branched simply at the base from a small taproot. Leaves in a basal rosette and cauline, spathulate to narrowobovate, 1-8 cm long, 2-12 mm wide, obtuse to broad-acute, gland-tipped, palegreen, with glandular hairs and multi-septate hairs and with sparse long fine tangled 
hairs on the margins. Inflorescence a globose terminal compound head. Scape strawcoloured to reddish, glandular with translucent globules and with a few multi-septate hairs. Compound head 7-28 mm diam., with c. 30-60 partial heads. Partial heads prominently pedunculate, with 6-11 florets; main bract of the partial involucre ovatecordate to almost circular, decurrent on the peduncle, with a small ovate to deltoid glandular, herbaceous stereome, finely and sparsely woolly at the base, and with a colourless membranous lamina. Corolla golden-yellow; lobes broad-acute, conspicuously papillate on the inner surface; achenes $1.5-2 \mathrm{~mm}$ long, with fine, dense, appressed, short, silky hairs; pappus of 10-16 colourless, plumose bristles $2-3 \mathrm{~mm}$ long.

DERIVATION: From the Greek haplo, single, and -rhiza, root; referring to the single taproot.

FLOWERING PERIOD: Early spring to early summer.

НАвітAт: On heavy soils, on floodplains and in damp situations.

DistribuTION: In the western and far western divisions of New South Wales, northwestern Victoria, south-western Queensland, southern Western Australia, and in South Australia.

Can be distinguished from all other Craspedia species by its single taproot.

This species was referred to as sp. O in Jacobs \& Pickard (1981).

Selected specimens: QueEnSLANd: Maranoa: $7 \mathrm{~km} \mathrm{~W}$ of St George, Trapnell 288 \& Williams, 1 Sep 1973 (BRI). NEw South WaLes: North Western Plains: Grawen Creek, S of Collarenebri on Cryon road, Thompson 2621, 27 Aug 1976 (NSW). South Far Western Plains: Menindee Billabong near Darling River, $6 \mathrm{~km}$ south of Menindee on Pooncarie road, Corrick 7334, 30 Aug 1981 (NSW, HO, AD, MEL). South Australia: Northern Lofty: Barrier Highway, North Terowie, Catford 205, 24 Sep 1984 (AD). Western Australia: Eastern Goldfields, Mann, May 1918 (NSW 218800).

\section{Acknowledgements}

We wish to thank Karen Wilson for the Latin diagnoses, and Andrew Denham, Lani Retter, Leonie Stanberg and Ross Rowe for technical assistance. We are grateful to the Heads of AD, PERTH, BRI, DNA, MEL, CANB, CBG, and HO for the loan of specimens that have made this study possible. The work has been in part supported by grants from the Australian Biological Resources Study, which we gratefully acknowledge.

\section{Reference}

Jacobs, S.W.L. \& Pickard, J. (1981) Plants of New South Wales (Govt Printer: Sydney). 